\section{Kastamonu Eğitim Dergisi Kastamonu Education Journal}

Eylül 2019 Cilt:27 Sayı:5

kefdergi.kastamonu.edu.tr
Başvuru Tarihi/Received: 14.03.2018

Kabul Tarihi/Accepted: 21.12.2018

DOI: 10.24106/kefdergi.2863

\title{
Makine Öğrenmesi Tekniklerini ve Kolb Öğrenme Stilleri Envanterini Kullanarak Öğrencilerin Öğrenme Stillerinin Belirlenmesi için Bir Model Önerisi
}

\section{A Model Proposal to Determine Learning Styles of Students by Using Machine Learning Techniques and Kolb Learning Styles Inventory}

\author{
Elif KARTAL ${ }^{1}$, Sezer KÖSE BIBBER ${ }^{2}$, Mahir BiBER ${ }^{3}$, Melodi ÖZYAPRAK ${ }^{4}$, İrfan ŞiMŞEK ${ }^{5}$, Tuncer CAN ${ }^{6}$ \\ Öz
}

Öğrenme stillerini önceden belirlemek, öğrenme ortamının tasarımında, öğretim üyesinin ders içeriğini hazırlamasında ve özellikle öğrencinin öğrenme sürecinde önemli bir rol oynamaktadır. Kolb Öğrenme Stilleri Envanteri (KÖSE), öğrenme stillerini belirlemede en yaygın kullanılan araçlardan birisidir; ancak diğer araştrrmalar, ölçekler veya psikolojik testlerde olduğu gibi KÖSE'nin de uygulama ve değerlendirme aşamalarında, soruların yanlış anlaşılması veya boş geçilmesi gibi bazı problemlerle karşılaşılabilir. Bu çalışmada; makine öğrenmesi teknikleri ve KÖSE Versiyon III (KÖSE-III) kullanılarak öğrencilerin öğrenme stillerini belirlemeye yönelik bir model önerisi geliştirmek ve bu modeli temel alan, web ve mobilden erişilebilen bir uygulama geliştirmek amaçlanmaktadır. Bu amaçla, KÖSE-III'te verilen durumlara yönelik Kolb'un orijinal değerlendirme yönteminden farklı olarak öğrencilerden kendilerine en uygun gelen seçeneği seçmeleri istenmiş ve öğrencilerin yaş ve cinsiyet bilgileri de alınarak araştırmanın veri seti oluşturulmuştur. Makine öğrenmesi tekniklerinden k-En Yakın Komşu Algoritması, C4.5 Karar Ağacı Algoritması ve Naive Bayes Sınıflandırıcısı kullanılarak en iyi performansı gösteren model seçilmiştir. Araştırma kapsamında geliştirilen uygulama e-öğrenme sistemlerine kolaylıkla entegre edilebileceğinden; öğreticilerin, öğrencilerin öğrenme stillerini belirleme süreçlerini kolaylaştırması, buna bağlı olarak eğitim etkinliklerinin öğrenci merkezli tasarlanmasına imkân tanıması ve daha çok öğrenciye ulaşılan bilimsel çalışmaların yapılabilmesi açısından bu çalışmanın önemli olduğu düşünülmektedir.

\section{Anahtar Kelimeler: Kolb öğrenme stilleri envanteri, makine öğrenmesi, öğrenme stilleri}

\section{Abstract}

Determining the learning styles in advance plays an important role in the design of the learning environment, in the preparation of the instructor's course content, and in the learning process of the learner in particular. Kolb's Learning Style Inventory (KLSI) is one of the most widely used tools to determine learning styles. However, some problems such as misunderstood or unanswered questions can be encountered in application and evaluation stages of the KLSI as in the other questionnaires, scales or psychological tests. The aim of this study is to develop a model proposal for determining learning styles of students by using machine learning techniques and KLSI Version III (KLSI-III) and based on this model to develop an application that can be accessible both online and on mobile devices. For this purpose, data set of this research was created by adding the age and gender attributes to the answers given as the most appropriate option to KLSI-III (unlike Kolb's original evaluation method). Machine learning techniques such as k-Nearest Neighbor Algorithm, C4.5 Decision Tree Algorithm and Naive Bayes Classifier were applied to this data set and the model with the highest performance has been selected out of this data set. As the application developed within the scope of this study can be easily integrated into e-learning systems; it is thought that it is important for the teachers to facilitate the process of determining the learning styles of the students and accordingly to enable the student-centered design of the training activities and the scientific studies reaching more students.

Keywords: Kolb's learning styles inventory, learning styles, machine learning techniques

1 İstanbul University, Informatics Department, İstanbul, Turkey; https://orcid.org/0000-0003-4667-1806

2 İstanbul University-Cerrahpaşa, Hasan Ali Yücel Faculty of Education, İstanbul, Turkey; https://orcid.org/0000-0001-5807-5185

3 İstanbul University-Cerrahpaşa, Hasan Ali Yücel Faculty of Education, İstanbul, Turkey; https://orcid.org/0000-0003-4044-6966

4 İstanbul University-Cerrahpaşa, Hasan Ali Yücel Faculty of Education, İstanbul, Turkey; https://orcid.org/0000-0003-1891-8218

5 İstanbul University-Cerrahpaşa, Hasan Ali Yücel Faculty of Education, İstanbul, Turkey; https://orcid.org/0000-0002-7481-5830

6 İstanbul University-Cerrahpaşa, Hasan Ali Yücel Faculty of Education, İstanbul, Turkey; https://orcid.org/0000-0001-8145-0772

Attf / Citation: Kartal, E., Köse Biber,Biber, M.,Özyaprak, M, Şimşek, İ.,\& Can T.(2019). Makine öğrenmesi tekniklerini ve kolb öğrenme stilleri envanterini kullanarak öğrencilerin öğrenme stillerinin belirlenmesi için bir model önerisi.Kastamonu Education Journal, 27(5), 1875-1892. doi:10.24106/ kefdergi.2863 


\section{Extended Abstract}

Students can learn in many different ways. Some students learn best by seeing and hearing, some learn best by memorizing, while others learn best by visualizing and creating mathematical models. How students learn best and what methods they employ have always been an issue for educators. Determining learning styles of the learners is the prerequisite for creating learning environments suitable for the learning styles of the students. It is seen that there are quite a variety of assessment tools used in the determination of learning styles in the literature (Mumford \& Honey, 1992; Riding, 1991; Dunn et al., 1989; Kaufmann, 1989; Kolb, 1985; Gregorc, 1982; Witkin et al., 1971; Kagan et al., 1964). Kolb's Learning Style Inventory (KLSI) (Kolb, 1984) is one of the most widely used measurement tools among them. Also, the third version of KLSI (KLSI-III), which was developed by Kolb (1999) in accordance with Experiential Learning Theory, translated into Turkish by Evin Gencel (2006) and its validity and reliability have been evaluated. However, some problems such as misunderstood or unanswered questions can be encountered in application and evaluation stages of the $\mathrm{KLSI}$ as other questionnaires, scales or psychological tests.

Machine learning is one of the sub-research fields of artificial intelligence. The idea behind machine learning is basically to develop computer programs that can learn just like humans. Machine learning techniques are often preferred for decision-making and prediction problems in the present day when concepts like knowledge extraction from data and big data analysis are discussed. In machine learning, there are two main types of learning methods, supervised and unsupervised. The main difference between them is that the target attribute to be estimated (dependent variable) is included in the data set in the supervised learning method and not in the unsupervised. Supervised learning can be used to solve the classification problems where the target attribute has two or more classes (Brownlee, 2016b; Kotsiantis, 2007). Learning styles of students in KLSI-III are classified as "Converging", "Diverging", "Assimilating", and "Accommodating", so the problem of determining learning styles of students can be examined under supervised learning. For this reason, in the scope of this study, the idea that machine learning can be used as an alternative method in evaluating KLSI-III is revealed.

In this study, it is aimed to develop a model proposal by using machine learning techniques and KLSI-III for determining the learning styles of students and based on this model to develop an application that can be accessible both online and on mobile devices. As the application developed in this study can be easily integrated into e-learning systems, it is thought that this work is important in terms of facilitating the process of determining the learning styles of the students, thus enabling the student-centered design of the educational activities and the scientific studies reaching more students. Furthermore, in KLSI-III, students are asked to list four options in terms of their suitability according to the given case. However, in practice, it is observed that some students often ignore the ranking and choose a single option that they see most appropriate among the options given. However, even if they did sorting, it was observed that they gave 1 point instead of 4 points to the most suitable option. This behavior is due to the idea that the most appropriate option for the given situation is in the first place. Similar problems in practice have also been emphasized in the work done by Botsios et al. (2008). Therefore, in the application process of KLSI-III by using machine learning and selecting the most appropriate option may provide an important contribution to the literature. In this case, the application structure of KLSI-III will be simplified and the application time will be shortened.

In this study, survey model is used to determine the learning styles of the students with KLSI-III as a research model. The sample of the study is composed of 284 students selected by simple random sampling from the students studying at the faculty of education of a state university in istanbul. KLSI-III and a questionnaire prepared by the researchers to determine the age, gender, class, period, the department in which they are studying and the type of school they graduated are used to collect data. CRoss-Industry Standard Process for Data Mining (CRISP-DM) (Shearer, 2000) is used for data analyses by considering the close relationship between data mining and machine learning.

The data set of this research was created by adding the age and gender attributes to the answers given as the most appropriate option to KLSI-III (unlike Kolb's original evaluation method). Machine learning techniques such as k-Nearest Neighbor Algorithm, C4.5 Decision Tree Algorithm and Naive Bayes Classifier were applied to this data set and the model with the highest performance is selected among them. Hold-out method was used as the model performance evaluation technique and performance of three machine learning techniques are evaluated in terms of accuracy, sensitivity, specificity, positive predictive value, negative predictive value, and F1 score. Accuracy, which is usually preferred as a model performance evaluation measure in the literature (Emre, 2017; Özen, 2016; Douglas et al., 2011; Williams et al., 2006), is taken into consideration for final comparison of the performance of three different machine learning algorithms.

As a result of the analysis made, the best performance is obtained with C4.5 decision tree algorithm with 0.659 accuracy. The model obtained with the C4.5 Decision Tree Algorithm revealed that the 9th question asked for the best learning path was the most decisive factor (root node) in the decision tree. The performance of C4.5 decision tree model was followed by the k-Nearest Neighbor Algorithm with 0.646 accuracy and Naive Bayes Classifier with 0.622 accuracy.

The model generated from the C4.5 Decision Tree Algorithm, which is the machine learning algorithm that gives the best accuracy value in the analyses, has been turned into an application which can be accessed both online and on mobile devices. The visitor can see the results that show the learning style prediction and the performance evaluation of the C4.5 Decision Tree Algorithm model by clicking on the "Predict!" button after marking the most appropriate options in the application. It is believed that this application will enable the increase of awareness on the importance of the learning styles and contribute to the creation of personal learning environments by integrating similar applications, especially 
with LMS. In addition, it can be applied to the students at the beginning of the education period in the classroom education, so that the learning styles of the students can be determined. Thus, the trainer can regulate or enrich the curriculum throughout this period. As a natural result of this, the academic success of the students and their motivation towards the lessons are expected to increase (Ming, 2004; Bilgin \& Durmuş, 2003; Kılıç, 2002).

It is important to develop such applications on questionnaires, scales or psychological tests which are important in the field of education by using machine learning techniques in future studies. In addition, by choosing the most significant questions from the measurement tools with feature selection methods, the forms can be shortened and complicated structures can be simplified. Thus, the problems such as lack of motivation of the students in practice, prejudice, misunderstanding of the questions and leaving the questions blank, as expressed by Botsios et al. (2008), or unanswered that result from the excessive number of items in the assessment will be minimized.

It is recommended that applications can be carried out by increasing the number of samples in the dataset for future studies related to the subject. It is believed that higher accuracy values can be achieved in analysis with more data (Raut, 2017; Brownlee, 2016a). The sample of this study is composed of higher education students. Similar analyses can be performed on different sets of sample groups to compare the obtained results. This study can be extended by performing the analyses with different machine learning techniques. 


\section{Introduction}

Students can learn in many different ways. Some students learn best by seeing and hearing, some learn best by memorizing, while others learn best by visualizing and creating mathematical models. It has always been an issue for educators how students learn best and what method they employ. It is also important to create learning environments where appropriate learning methods are used as well as the abilities inherent in the learning of the students and their readiness levels. Nowadays, the concept of learning style in the learning environments is at the foreground. The learning style is a concept that arises from the view that each individual may have different ways of accessing information (Pashler, McDaniel, Rohrer, \& Bjork, 2009) and this term has recently entered into the terminology of learning as an extension of David A. Kolb's "experiential learning theory" (Peker, 2003; Poon Teng Fatt, 2000). Kolb (1984) refers to learning styles as generalized differences in learning orientations. According to Dunn \& Dunn (1993), the learning style is a way that differs in every individual, begins with the individual concentrating on new and difficult knowledge, and continues with the process of grasping information and placing it into the mind.

Determining learning styles of the learners is the prerequisite for creating learning environments suitable for the learning styles of the students. It is seen that there are quite a variety of assessment tools used in the determination of learning styles in the literature (Mumford \& Honey, 1992; Riding, 1991; Dunn, Dunn, \& Price, 1989; Kaufmann, 1989; Kolb, 1985; Gregorc, 1982; Witkin, Oltman, Raskin, \& Karp, 1971; Kagan, Rosman, Day, Albert, \& Phillips, 1964). Kolb's Learning Style Inventory (KLSI) (Kolb, 1984) is one of the most widely used measurement tools among them. However, some problems such as misunderstood or unanswered questions can be encountered in application and evaluation stages of the KLSI as other questionnaires, scales or psychological tests. In this study, it is aimed to develop a model proposal by using machine learning techniques and KLSI Version III (KLSI-III) for determining the learning styles of students and based on this model to develop an application that can be accessed both online and on mobile devices.

\section{Learning Styles}

Today, the idea of personalizing learning environments is becoming increasingly prevalent. As one problem may have more than one solution, an individual may need to use a different way or a different learning environment to solve the problem easier and faster. That individuals have different learning characteristics (Gülbahar, 2005) and access information through different ways confirm the learning styles (Pashler et al., 2009). In order to ensure maximum efficiency in educational activities, it is necessary to determine the learning characteristics of the individuals and to design the learning activities in accordance with these characteristics. Duff \& Duffy (2002) and Mumford \& Honey (1992) defined the learning style as the ability and perception of cognitive, affective, and psychomotor domains when each student interacted with the classroom environment and the school environment. Brown (2000), on the other hand, described the learning style as a way of perceiving and processing information in individual learning situations. Every individual can learn in a variety of ways, but the easiest and the best learning happens through the most appropriate learning style for the individual (Kinshuk, Liu, \& Graf, 2009).

When the related literature is reviewed, many learning style models that are used to determine the learning styles of individuals could be observed (Brown, Cristea, Stewart, \& Brailsford, 2005; Cassidy, 2004). However, in the literatu$\mathrm{re}$, it is seen that these learning styles are classified in many different ways considering the main characteristics of the learning styles. When the classification are examined in general, it is evident that some researchers take neurological and neuropsychological research as basis, while others consider how individuals perceive, organize and process information (Zajacova, 2013). Besides, many theoreticians are presenting learning styles with cognitive-centered, personality-centered and activity-centered learning approaches (Cassidy, 2004; Grigorenko \& Sternberg, 1995). Accordingly, a classification of learning styles models commonly used in the literature according to learning approaches is presented in Table 1 (Zhang, Sternberg, \& Rayner, 2011);

Table 1: The classification of Learning Styles (Zhang et al., 2011)

\begin{tabular}{ccc}
\hline Cognitive-centered approaches & Personality-centered approaches & Activity-centered approaches \\
\hline $\begin{array}{c}\text { Sternberg Thinking Styles } \\
\text { Witkin Field-Independent and Field-Dependent } \\
\text { Styles }\end{array}$ & Myers-Briggs Types & Biggs Study Process \\
Kagan Impulsive/Reflective Styles & Holland-RIASEC & Dunn and Dunn Learning Styles \\
Torrance Styles of Learning and Thinking & Kirton Adaptive Innovative Styles & Kolb Learning Styles \\
& & Grasha-Reichmann Learning Styles \\
& & Guilford Thinking \\
\hline
\end{tabular}

| Kastamonu Eğitim Dergisi, 27(5), 2019| 
According to Cassidy (2004) and Hein \& Budny (1999), it is also very important for the teaching process to identify and assess the learning styles that individuals possess. In addition, the most important condition for the learning is how one takes responsibility for their own learning. If the individuals know their own learning style and the characteristics of this learning style, they can act accordingly. This makes it easier for the individual to access ever-changing and growing information without needing any help. According to Babadoğan (2000), if the learning styles of the students are determined, the best way for them to learn can be estimated and accordingly the most appropriate learning environments can be created. The identification of the learning style of the individual allows the identification of learning preferences and this provides the guidelines and recommendations for improving the academic success and school performance of the individual (McKenna, Copnell, Butler, \& Lau, 2018; Moussa, 2014; Kharb, Samanta, Jindal, \& Singh, 2013). If each student is faced with learning situations appropriate to their learning style, it could be easier to learn and succeed (Veznedaroğlu \& Özgür, 2005). On the contrary, learning outcomes are negative when students are confronted with situations that are inconsistent with their learning styles, leading to negative behavior in the future (Visser, McChlery, \& Vreken, 2006). In addition, knowing the individuals' learning styles also help them become effective problem solvers (Gilakjani, 2012).

Some research findings indicate that there is a positive and meaningful relationship between students' learning styles and their academic achievement (Okur \& Bahar, 2010; Dunn et al., 2009; Lovelace, 2005; Felder, Felder, \& Dietz, 2002; Griggs \& Dunn, 1996). In addition to the academic achievements the learners' learning styles also have important learning implications on their course attendance, problem solving strategies, attitudes towards learning, learning motivations, and basic skills (Li et al., 2014; Ghazivakili et al., 2014; Dunn et al., 2009; Kinshuk et al., 2009; Metallidou \& Platsidou, 2008; Tanabe, 2006; Vermunt \& Vermetten, 2004; Simpson \& Du, 2004). According to Ekici (2003), learning styles have a great influence on the ability of individuals to understand the difference between right and wrong in career choice, the ability to seize their leisure time and to express themselves better.

\section{Machine Learning}

Machine learning is one of the sub-research fields of artificial intelligence. The idea behind machine learning is basically to develop computer programs that can learn just like humans. Machine learning techniques are often preferred for decision-making and prediction problems in the present day when concepts like knowledge extraction from data and big data analysis are discussed. Machine learning can be understood from the definition of Mitchell (1997) "If the performance of a computer program measured by $P$ in tasks $T$ increases with experience $E$, then it is said that the computer program learns from experience $\mathrm{E}$ by using some class of $\mathrm{T}$ tasks and performance measure $\mathrm{P}^{\prime \prime}$. The computer program, underlying the definition, is accepting the data while solving the problem as an experience similar to that of the human and learning the solution of the problem this way (Balaban \& Kartal, 2018). The performance ensures the level of learning and can be evaluated by some evaluation techniques and measures. In machine learning, there are two main types of learning methods, supervised and unsupervised. The main difference between them is that the target attribute to be estimated (dependent variable) is included in the data set in the supervised learning method and not in the unsupervised. Supervised learning can be used to solve the classification problems where the target attribute has two or more classes (Brownlee, 2016b; Kotsiantis, 2007).

In this study, the determination of students' learning style problem is considered as one of supervised learning problem in machine learning because learning styles of students is determined by using KLSI-III calculation technique before machine learning analysis and this variable is considered as the target attribute. So, this target attribute behaves like a guide for supervised learning algorithms such as k-Nearest Neighbor Algorithm, C4.5 Decision Tree Algorithm, and Naïve Bayes Classifier to make them learn the structure of the data (hidden patterns/information inside the data). k-Nearest Neighbor Algorithm uses the distance between observations to make predictions for new ones. C4.5 Decision Tree Algorithm depends on calculating uncertainty (entropy) based measures in dataset and at the end of the modeling process it creates a decision tree. So, important rules can be derived from this tree to make decision. Naïve Bayes Classifier is based on Bayes Theory which is fundamental and commonly used theorem in probability problems in statistics. Result of this technique indicates the class of a new observation in terms of probability values. More detailed explanations about these algorithms used in this study are given in below.

k-Nearest Neighbor Algorithm: This algorithm is based on closeness and distance of samples. Where $\mathrm{x}$ is the sample to be classified and $D$ is the current dataset, the algorithm is composed of the following steps (Larrañaga, 2006):

- The distance $\mathrm{d}$ between $\mathrm{x}$ and each example in the $\mathrm{D}$ dataset is estimated.

- d distances are ordered from small to large. 
- $\quad \mathrm{k}$ samples closest to $\mathrm{x}$ are selected from dataset $\mathrm{D}$.

- The most frequent repeating class label is assigned to $x$.

C4.5 Decision Tree Algorithm: This algorithm developed by J. Ross Quinlan (Han \& Kamber, 2006). The C4.5 decision tree algorithm is an advanced model of the ID3 algorithm. C4.5 can work with both categorical and numerical data types, not just categorical. The algorithm creates a decision tree (rule tree), using the dataset. It uses rules such as "if", "and" to generate rules for problem solving. C4.5 performs entropy-based partitioning while forming the tree structure. Split Info and Gain Ratio are used (Han \& Kamber, 2006).

Naive Bayes Classifier: Naive Bayes is a classifier based on Bayes Theorem. It assumes that the attributes used for estimation are independent of each other (Sayad, 2017). Calculation is carried out with the frequency table for categorical attributes and discretization of numeric attributes or the assumption that the numerical attributes follow a normal distribution (Garg, 2013).

\section{Determining the Learning Styles}

Determining the learning styles in advance plays an important role in the design of the learning environment, in the preparation of the instructor's course content, and in the learning process of the learner in particular (Xu \& Shi, 2018; Kahtz \& Kling, 1999). When the literature in the field is examined, it can be seen that in order to determine the learning styles many assessment tools based on the scoring method have been developed. Since learning styles can be identified as one of the most fundamental issues to be addressed in terms of quality of education, a number of assessment tools have been developed for determination of learning styles (Mumford \& Honey, 1992; Riding, 1991; Dunn et al., 1989; Kaufmann, 1989; Kolb, 1985; Gregorc, 1982; Witkin et al., 1971; Kagan et al., 1964). There are two main reasons why assessment of learning styles is so widespread (Pashler et al., 2009): The first of these is an attempt to obtain valid and reliable data on the personal characteristics of the individual. The second is to help people to become aware of their learning style and to choose appropriate learning materials. People at this point will be as autonomous as possible in terms of learning (Logan \& Thomas, 2002). In this part of the study, learning style models commonly used in literature have been shared in below.

KLSI is one of the most popular scales that is frequently used in the field to determine the learning styles of the students. According to Kolb, the learning processes of individuals differ according to the preferred form of perception (from concrete to abstract) and the preferred form of learning (from active trials to reflective observations) (Pashler et al., 2009). Kolb divides its learning styles into four levels: Diverger, Assimilator, Accommodator and Converger. Since the KLSI is used as a data collection tool in the study, the information about these levels and inventory is discussed in detail in the method section of the study.

Another widely used learning style scale is the Dunn and Dunn Learning Style Model developed by Dunn et al. (1989). Dunn, Beaudry, \& Klavas (1989) argue that differences in learning styles are influenced by both biological and developmental characteristics. Differences in these characteristics cause the influence and the meaning of the teaching methods to be different for all students. In this respect, five learning style elements are included on Learning Style Inventory (Riding \& Rayner, 2013): (1) environmental stimulus, (2) emotional stimulus, (3) sociological stimulus, (4) physiological stimulus, and (5) psychological stimulus.

Another example of the learning style scales is the Group-Embedded Figures Test developed by Witkin et al. (1971) after their experimental studies (Şimşek, 2007). This scale aims at measuring the ability of individuals to separate on the basis of perceptual activity, and as a result of the scale, two learning styles are obtained as field-dependent and field-independent (Şimşek, 2007). Later, Gregorc (1982) developed a self-assessment scale called The Style Delineator. On this ten-item scale, scores represent the order in which the participant chooses the most preferred and the least preferred. Each point can only be used once, and each word represents a learning style. The scores collected for different categories within the scale represent the participant's learning style. These categories are (a) concrete-sequential, (b) abstract-sequential, (c) concrete-random, (d) abstract-random.

Another learning style model introduced in 1994 was Felder and Silverman Learning Style Model (FSLSM) (SamanCI \& Keskin, 2007). According to Felder \& Silverman (1988), learning takes place in a two-step process; the first step includes the perceiving the information, the second step includes the processing of the information perceived. FSLSM offers four independent dimensions namely processing, perception, input, and understanding. Preferences of learners are defined to process information (active/reflective), perceive information (sensing/intuitive), receive information (visual/verbal), and organize (sequential/global) information (Maaliw \& Ballera, 2017). In addition, according to Riding 
(2002), who treat learning styles in cognitive domain, a learning style is the approach individuals prefer to organize and express the knowledge. Developed by Riding (1991) Cognitive Style Analysis measuring tool is based on the principle that both of the wholist-analytic and verbal-imagery dimensions can be measured directly (Peterson, Deary, \& Austin, 2003).

When the scales developed to determine the learning styles are examined in general, the results obtained from each of the scales are evaluated and interpreted by the experts. This method is very costly and laborious in terms of insufficiency of the number of experts and difficulties of reaching the subjects. This clearly demonstrates the need for alternative methods using today's advanced technologies to overcome current drawbacks. In this respect, when the related literature is examined, it is seen that the machine learning and data mining techniques are used in determining the learning style of the person (Maaliw \& Ballera, 2017; Rajper, Shaikh, Shaikh, \& Ali Mallah, 2016; Petchboonmee, Phonak, \& Tiantong, 2015). In addition, each of the standard methods that model learning styles divides learning styles into certain categories and places individuals in these categories according to their scores. For this reason, in machine learning studies, the determination of learning styles is mostly considered as a classification problem in which supervised learning algorithms are used.

In the literature, it can be seen that decision tree algorithms such as C4.5 Decision Tree Algorithm (is represented as J48 in WEKA data mining software) and Random Forest Algorithm, which use supervised learning and are preferred for classification problems, is mostly used to determine learning styles. Maaliw \& Ballera (2017) determined learning styles of students of Computer Programming I course in Southern Luzon State University in Philippines with an Index of Learning Styles (ILS) questionnaire based on FSLSM. The learning styles were associated with behaviors of the students on Moodle Learning Management System (LMS). Then, the performance of four different classification techniques (Naive Bayes, Logistic Regression, Conjunctive Rule and J48) were compared based on interaction logs and navigation patterns. According to research findings, J48 decision tree classifier has given the best accuracy (87.42\%). Liyanage et al. (2016) used almost the same techniques (Bayesian network, Naive Bayes, J48 and Random Forest algorithms) to derive learners' learning styles based on Moodle LMS log data. Authors developed a new module which predicts learning style based on the best performing algorithm (J48 with accuracy 65.26\%). Truong (2015) is another researcher who presented a proposal for the development of a system that classifies learning styles through students' online learning behaviors. Narli, Aksoy, \& Ercire (2014) aimed to determine learning styles of students and to explore the relationships between them. For this purpose, Turkish translation of Grasha-Riechmann Student Learning Styles Inventory was applied to prospective elementary mathematics teachers at Dokuz Eylül University. Network graph, C5.0 decision tree algorithm and association rules were used in data analysis. Pantho \& Tiantong (2016) classified learners' VARK (Visual, Aural, Read / Write, Kinesthetic) learning style with accuracy of $83.40 \%$ using C4.5 algorithm.

The performance of probability based techniques such as Bayesian networks are also evaluated to detect learning style of a student in a web based education system (García, Amandi, Schiaffino, \& Campo, 2007). In the evaluation step, the study was conducted with 27 computer science engineering students who take Artificial Intelligence Course. At the end of the study, the learning styles of students were obtained from Bayesian networks compared with results obtained with ILS questionnaire. Only perception, processing and understanding dimensions was included in the analysis. Also, Rajper et al. (2016) used a Bayesian network to predict the learning style of students who were registered to computer science courses over the LMS. In their study, first they used KLSI to determine students' learning styles. Then an online survey was used to collect data about activities of students on LMS. The proposed model again is suggested for personalized e-learning systems.

Furthermore, some studies in the literature used hybrid or more advanced supervised learning techniques such as NBTree, artificial neural networks and fuzzy logic. Hmedna, El Mezouary, Baz, \& Mammass (2017) have worked with artificial neural networks to identify and track learning styles of the learners to recommend more appropriate materials on MOOCs environment. Uysal (2010) aimed to model ILS with fuzzy logic to solve the uncertainties in instruction environments. Modelled fuzzy inference system is suggested for intelligent learning systems and computer-aided instruction environments. A similar study is performed by Uysal, Balbal, Mülayim, Özdemir, \& Albeyoğlu (2016). They proposed a learning style inference system to increase the success of a student in education by using fuzzy logic and Dunn Learning Style. Abdullah, Daffa, Bashmail, Alzahrani, \& Sadik (2015) investigated the effect of learning styles of learners on the performance of e-learning environment and obtained the best accuracy value with NBTree algorithm in these analyzes performed using WEKA. Petchboonmee et al. (2015) performed learning style classification and investigated the effectiveness of Kolb's classification of experimental learning style by using WEKA. When some general questions such as gender, educational level, and Kolb's 32-item experiential learning style classification questionnaire were used 
to analyze J48's data collected from 502 students, it is concluded that $\mathrm{J} 48$ has the best classification performance with $85.65 \%$ accuracy rate among Naive Bayes and NBTree algorithms.

There are also some other studies in the literature in which a method/model/framework is developed or proposed for learning style prediction (Helmy, Abdo, \& Abdallah, 2016; Yang, Huang, Gao, \& Liu, 2014). In the light of the studies summarized above, conducting a research, in which an alternative model for determining the learning styles of the students was presented by using machine learning techniques, was considered as a significant contribution to the field.

The studies summarized above aim to determine or predict the learning style of learners with machine learning and data mining techniques such as Bayesian Network, Naive Bayes, Random Forest, NBTree, and C4.5. Machine learning techniques use the data as experience to make decisions/predictions for a new observation for pre-determined tasks. So, these techniques are applied to the existing data for determining learning styles problem. The data sometimes can be an LMS log, sometimes can be the answers of a questionnaire, etc. In addition, these techniques have the ability of creating models which learn from the data. The focus is on building models/programs which can learn and make decisions for a new observation in a specific domain. According to the studies summarized above machine learning techniques can be used as well as other techniques such as KLSI, ILS etc. to determine learning styles. These models provide the determination of an individual's learning style by using the power of machine learning and data mining.

In this context, the problem sentence of this study is determined as "to develop a model proposal for determining learning styles of higher education students by using machine learning techniques and KLSI-III, and based on this model to develop an application that can be accessible both online and on mobile devices". In this way, sub-problems of research are: (1) What are the results obtained from the performance evaluation of the k-Nearest Neighbor Algorithm? (2) What are the results of the C4.5 Decision Tree Algorithm's performance evaluation? (3) What are the results of the Naïve Bayes Classifier's performance evaluation? Considering these sub-problems, it is aimed to find the machine learning model that gives the best performance in the research and to facilitate the process of applying and based on this model evaluating KLSI-III by developing an application which is accessible both online and on mobile devices. As the application developed in this study can be easily integrated into e-learning systems by using its URL, it is thought that this work is important in terms of facilitating the process of determining the learning styles of the students, thus enabling the student-centered design of the educational activities and the scientific studies reaching more students. Authors believe that once the best model is created, the determination process will be easier, and the model can be easily integrated to online learning platforms or can be easily applied to students in the classroom with a simple user interface. Moreover, the learning style of a student is determined by using only KLSI-III is performing with the scores that come separately from different options of the items. Students are asked to list four options in terms of their suitability according to the given case. However, in practice, it is observed that some students often ignore the ranking and choose a single option that they see most appropriate among the options given. Even if they did sorting, it was observed that they gave 1 point instead of 4 points to the most suitable option. This behavior is due to the idea that the most appropriate option for the given situation is in the first place. Similar problems in practice have also been emphasized in the work done by Botsios, Georgiou, \& Safouris (2008). In this study unlike the other studies in the literature, in response to each question in KLSI-III, authors only consider the answer that participants indicated as "only the most appropriate option" rather than "the order of relevance" in that question. This characteristic of this study is believed to minimize student errors during the KLSI-III application process. In this case, the application structure of KLSI-III will be simplified, and the application time will be shortened.

\section{Method}

\section{Research Model}

The survey model is used in this study. Survey model aims to describe an existing situation as it is. An event, an individual or an object, which is the subject of the research, is tried to be defined within its own conditions and as it is. No effort is made to change or to influence them in any way. The important thing is to be able to observe and determine what is wanted to be known (Karasar, 2003). In this research, students' learning styles were determined with KLSI-III and also their age, gender, class, period, the department in which they are studying and the type of school they graduated were determined with the help of a questionnaire which is prepared by the researchers.

\section{The Sample of the Study}

In this study, convenience sampling has been used. The sample of the study is composed of 284 students selected by simple random sampling from the students studying at the faculty of education at a state university in istanbul. 80 of them are male and 204 of them are female. The age of participants in the survey ranged from 17 to 52 and the average age was 22.14. 


\section{Data Collection Tool}

In the scope of the study, the third version of the KLSI, which was developed by Kolb (1999) in accordance with Experiential Learning Theory and translated into Turkish by Evin Gencel (2006), and whose validity and reliability has been evaluated, has been used as data collection tool. In Kolb's learning model the individuals' learning styles are in cycle and with the learning style inventory the place of the individuals in this cycle is determined. There are four learning styles in this cycle. These are Concrete Experience (C.E.), Reflective Observation (R.O.), Abstract Conceptualization (A.C.), and Active Experimentation (A.E.) (Aşkar \& Akkoyunlu, 1993). Kolb's learning style is based on a bipolar dimension, depending on how one perceives and internalizes knowledge. While abstract conceptualization and concrete experience define how individuals perceive knowledge, reflective observation and active experimentation examine how individuals process or internalize knowledge (Gooden, Preziosi, \& Barnes, 2009). According to Kolb's learning model, there is no single form that determines the learning style of the individual. The learning style of each individual is a component of these four basic forms. These learning styles are "Accommodator", "Assimilator", "Diverger", and "Converger". The learning style cycle according to Kolb's learning model is shown in Figure 1. Evin Gencel (2006) explains KLSI-III as:

Version III, which is the final form of the inventory, has significant differences in evaluation and coding. Style names have been changed to "Converging", "Diverging", "Assimilating", and "Accommodating". The scale covers 12 cases with four options in each, as in the KLSI-I (1971) and KLSI-II (1981) versions. There is a quadrant rating scale with options to respond in the form for the most appropriate for each situation in the inventory, then the second appropriate, the third appropriate and the least appropriate. The four options in each item are scored between 1 and 4 . The lowest score that can be taken from the scale is 12 , the highest score is 48 . After this estimation, the combined points are calculated. Consolidated scores are obtained in the form of Abstract Conceptualization (A.C.) - Concrete Experience (C.E.) and Active Experimentation (A.E.) - Reflective Observation (R.O.), and the scores obtained from this process range from -36 to +36 . The positive score obtained from A.C. - C.E. indicates that the learning is abstract whereas the negative score indicates that the learning is concrete; similarly, A.E. - R.O. scores indicate whether the learner is active or reflective. When the inventory is evaluated, the combined scores are placed on the coordinate system shown in Figure 2. The number obtained by processing A.C. - C.E. is marked on $x$-axis, and the number obtained by processing A.E. - R.O. is placed on the $y$-axis, and the intersection of these two numbers indicates the learning style of the individual (Evin Gencel, 2006).

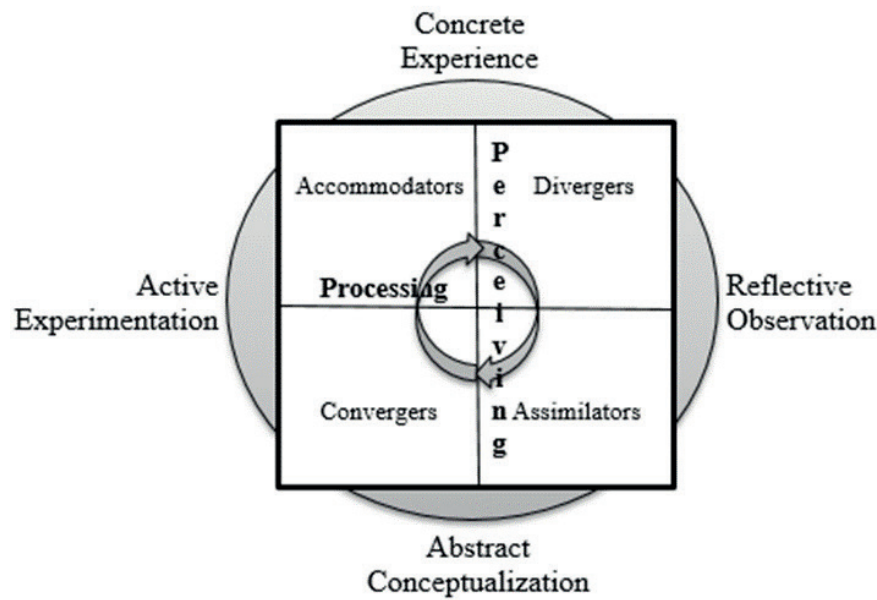

Figure 1: Learning Styles Cycle (Lowy \& Hood, 2004).

As a result of the validity and reliability study conducted by Evin Gencel (2006), the reliability coefficients of the four dimensions of the inventory (Cronbach $\alpha$ ) were found to vary between 0.71 and 0.80 . Since the reliability coefficients obtained are satisfactory, it has been interpreted that the result of "KLSI-III" can be applied in Turkey. Another data collection tool used by the researchers is a questionnaire prepared by the researchers to determine the age, gender, class, period, the department in which they are studying and the type of school they graduated. The survey was transferred to Google Forms and the dataset was created online. 


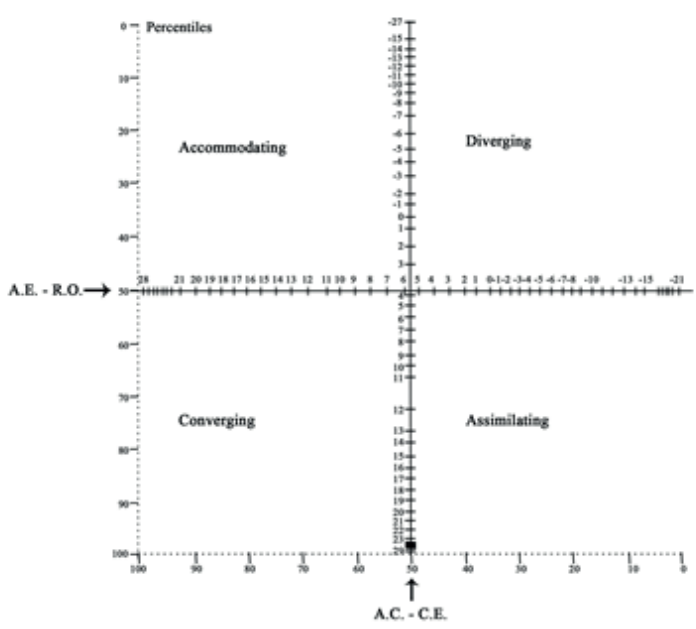

Figure 2: Kolb’s Learning Styles InventoryCoordinate System (Evin Gencel, 2006; Kolb, 1999).

\section{Data Analyses}

In this study, CRoss-Industry Standard Process for Data Mining (CRISP-DM) (Shearer, 2000) is used for data analyses by considering the close relationship between data mining and machine learning. CRISP-DM has the following six stages: (1) Business understanding, (2) Data understanding, (3) Data preparation, (4) Modeling, (5) Evaluation, and (6) Deployment.

(1) Business understanding: This step is presented in the introduction as a research problem.

(2) Data understanding and (3) Data preparation: Learning styles of students are determined by using KLSI-III calculation technique as mentioned in the previous section. Learning style attribute is considered as the target attribute for machine learning analysis. The class values of the target attribute are "Converging", "Diverging", "Assimilating" and "Accommodating". Of 284 students who took KLSI-III, 114 students (40.14\%) are labelled as "Converging", 95 (33.45\%) students are labelled as "Assimilating", 38 (13.38\%) students are labelled as "Accommodating", and finally 37 (13.03\%) students are labelled as "Diverging". $13 \%$ of the students are concrete and $87 \%$ of the students are abstract according to KLSI-III. Furthermore, $29 \%$ of them are reflective and $71 \%$ of them are active.

KLSI-III has 12 items and each item has four different options which should be scored by a student in terms of being the worst (1 point) or the best (4 points). The learning style of a student has been calculated with these scores that come separately from different options of the items. However, in this study unlike the other studies in the literature, in response to each question in KLSI-III, authors only consider the answer that participants indicated as "only the most appropriate option" rather than the order of relevance in that question. Because, in practice, it is observed that some students often ignore the ranking and choose a single option that they see most appropriate among the options given. Even if they did sorting, it was observed that they gave 1 point instead of 4 points to the most suitable option. This behavior is due to the idea that the most appropriate option for the given situation is in the first place. 12 questions in $\mathrm{KLSI}-\mathrm{III}$, age and gender attributes are also considered as predictive attributes. At this point, it is aimed to shorten time spent for all over the calculation and to make the process simpler. The data preparation process for the data analyses was terminated by removing three duplicate samples from the data set.

(4) Modeling: In algorithm selection process, the most commonly used algorithms as stated in "Determining the Learning Styles" section are considered. Three different machine learning classification techniques were applied to the data set to be able to predict the learning styles using machine learning techniques: k-Nearest Neighbor Algorithm, C4.5 Decision Tree Algorithm and Naive Bayes Classifier. Gower distance has been used in the k-Nearest Neighbor Algorithm for the reason that both the numerical and categorical attributes are in the data set.

Analyses were performed in the R programming language (cran.r-project.org, 2018) and RStudio (RStudio, 2018), caret (Kuhn, 2017), dprep (Acuna \& The CASTLE Research Group, 2015) (knngow() function for k-Nearest Neighbor Algorithm), e1071 (Meyer, Dimitriadou, Hornik, Weingessel, \& Leisch, 2017) (naiveBayes() function for Naive Bayes Classifier), plyr (Wickham, 2011), RWeka (Hornik, Buchta, \& Zeileis, 2009; Witten \& Frank, 2005) (J48() function for C4.5 
Decision Tree Algorithm), shiny (Chang, Cheng, Allaire, Xie, \& McPherson, 2017), shinythemes (Chang, 2016) packages have been used in the analyses.

(5) Evaluation: Finally, performance of three machine learning techniques have been evaluated in terms of accuracy (the proportion of correct predictions among all predictions in test dataset), sensitivity (the proportion of positive labelled samples that are correctly identified by the algorithm among all actual positive labelled samples), specificity (the proportion of negative labelled samples that are correctly identified by the algorithm among all actual negative labelled samples), positive predictive value (the proportion of positive labelled samples that are correctly identified by the algorithm among the samples that are predicted as positive), negative predictive value (the proportion of negative labelled samples that are correctly identified by the algorithm among the samples that are predicted as negative), and F1 score (harmonic mean of sensitivity and positive predictive value) (Balaban \& Kartal, 2018; Kartal \& Özen, 2017). In other words, it has been tried to determine how close or far the performance of the machine learning techniques to the KLSI-III evaluation results is. The model performance evaluation was performed by Hold-out method. $70 \%$ to $30 \%$ of the data has been divided into two parts for use in the training and testing of the algorithms. When the data set is separated, the samples are randomly selected, the class values of the target attribute are taken into consideration, and the stratified sampling is carried out while preserving the ratios of the class values of the target attribute in the training and test data set. Accuracy is usually preferred as a model performance evaluation measure in the literature (Emre, 2017; Özen, 2016; Douglas, Harris, Yuille, \& Cohen, 2011; Williams, Zander, \& Armitage, 2006), so in this study comparison of the performance of three different machine learning algorithms has been taken into consideration.

(6) Deployment: At the end of the CRISP-DM, a Shiny (RStudio, 2017a) application was developed with the best model that is accessible both online and on mobile devices by using "shinyapps.io" (RStudio, 2017b).

\section{Findings}

The performance results of the machine learning techniques performed to find the model that produces the closest results to the KLSI-III evaluation results are given in this section. Reflections of these findings into education are given in "Discussion, Conclusion and Recommendations" section.

Findings of the First Sub-Problem of the Research: "What are the results obtained from the performance evaluation of the k-Nearest Neighbor Algorithm?"

In order to obtain the parameter giving the best accuracy value, the analyses were repeated for $k$ values from 1 to 20 (Figure 3).

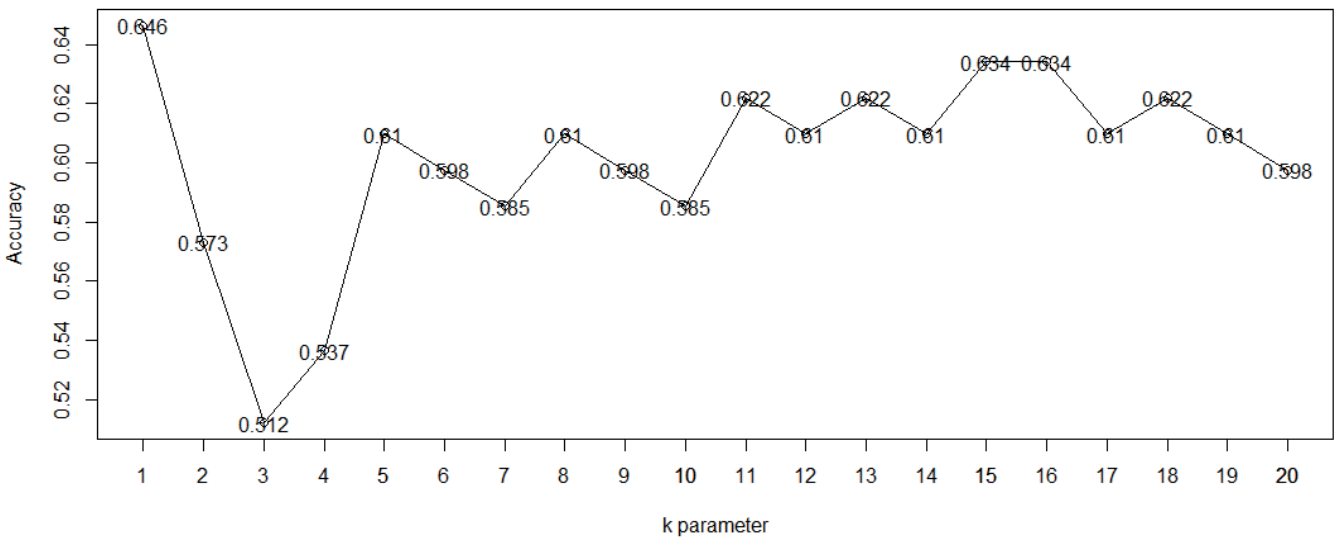

Figure 3: The accuracy values obtained from k-Nearest Neighbor Algorithm (from $k=1$ to $k=20$ ).

The best accuracy value was obtained for $0.646 \mathrm{k}=1$, with $\mathrm{k}=15$ and $\mathrm{k}=16$ with 0.634 accuracy, $\mathrm{k}=11, \mathrm{k}=13$ and $\mathrm{k}=18$ with 0.622 accuracy. All performance values obtained for $\mathrm{k}=1$ are given in Table 2 .

According to Figure 3, the neighbor number $\mathrm{k}$ is chosen as 1 because in this way, a new student's learning style, which is to be predicted, can easily be determined by looking into only the nearest student's learning style in the training dataset. This also saves time during the analysis.

In addition, the chosen model can predict the learning style of a student approximately $65 \%$ accurately. Table 2 shows the 
other performance evaluation metrics for each class of the target attribute. In other words, Table 2 shows the correct predictions of the model among all the predictions according to learning style types of the students ("Converging", "Diverging", "Assimilating", and "Accommodating"). Table 3 and Table 4 are also interpreted with similar thought in Table 2.

Table 2: The performance values obtained from Performance values obtained for $k=1$.

\begin{tabular}{lcccc}
\hline & Converging & Diverging & Assimilating & Accommodating \\
\hline Sensitivity & 0.7273 & 0.5000 & 0.6071 & 0.6363 \\
Specificity & 0.7143 & 0.9861 & 0.8704 & 0.9014 \\
Positive Predictive Value & 0.6316 & 0.8333 & 0.7083 & 0.5000 \\
Negative Predictive Value & 0.7955 & 0.9342 & 0.8103 & 0.9412 \\
F1 Score & 0.6761 & 0.6250 & 0.6538 & 0.5600 \\
\hline
\end{tabular}

Findings of the Second Sub-Problem of the Research: "What are the results obtained from Naive Bayes Classifier?"

Analysis of the Naive Bayes Classifier yielded an accuracy of 0.622 . The performance values of the results obtained from the analyses are given in Table 3.

Table 3: The performance values obtained from Naive Bayes Classifier.

\begin{tabular}{lcccc}
\hline & Converging & Diverging & Assimilating & Accommodating \\
\hline Sensitivity & 0.6667 & 0.5000 & 0.6786 & 0.4546 \\
Specificity & 0.7959 & 0.9306 & 0.8519 & 0.8873 \\
Positive Predictive Value & 0.6875 & 0.5000 & 0.7037 & 0.3846 \\
Negative Predictive Value & 0.7800 & 0.9306 & 0.8364 & 0.9130 \\
F1 Score & 0.6769 & 0.5000 & 0.6909 & 0.4167
\end{tabular}

Findings of the Third Sub-Problem of the Research: "What are the results Obtained from C4.5 Decision Tree Algorithm?"

In the decision tree resulting from the analyses, Question 9 initiated the first branching and it is seen that the degree of importance is higher when the learning style is decided. According to the obtained tree structure, the following rule deductions and similar conclusions can be made with an accuracy of 0.659:

- IF the person says "The best way of learning for me is taking what I feel into account", then the Learning Style = DIVERGING.

- IF the person says "Watching is the best way to learn" AND "While I am learning, I am watching without participating in the class", Learning Style = ASSIMILATING.

Table 4 shows all performance evaluation results obtained from the C4.5 Decision Tree Algorithm.

Table 4: The performance values obtained from C4.5 Decision Tree Algorithm.

\begin{tabular}{lcccc}
\hline & Converging & Diverging & Assimilating & Accommodating \\
\hline Sensitivity & 0.8485 & 0.6000 & 0.6429 & 0.1818 \\
Specificity & 0.6939 & 0.9583 & 0.8333 & 0.9859 \\
Positive Predictive Value & 0.6512 & 0.6667 & 0.6667 & 0.6667 \\
Negative Predictive Value & 0.8718 & 0.9452 & 0.8182 & 0.8861 \\
F1 Score & 0.7368 & 0.6316 & 0.6545 & 0.2857 \\
\hline
\end{tabular}

The model generated from the C4.5 Decision Tree Algorithm, which is the machine learning algorithm that gives the best accuracy value in the analyses, has been turned into an application which can be accessed both online and on mobile devices. The visitor can see the results that show the learning style prediction and the performance evaluation of the C4.5 Decision Tree Algorithm model easily by clicking on the "Predict!" button after marking the most appropriate options in the application. 


\section{Discussion, Conclusion and Recommendations}

In this study, it is aimed to develop a model proposal using machine learning techniques to determine the learning styles through KLSI-III. While the data set of the study was created, the age and gender characteristics of the students were considered together with the KLSI-III scale. Furthermore, unlike the original evaluation system of the KLSI-III, students were asked to select the option that was most appropriate for them in the given situations rather than ranking the options that determine their learning styles in terms of eligibility. Thus, it is aimed to prevent the frequently encountered problems such as students' getting tired and responding to questions without understanding during the application of the scales due to the long duration of the scales mentioned in the literature (Botsios et al., 2008). Accordingly, machine learning techniques such as k-Nearest Neighbor Algorithm, C4.5 Decision Tree Algorithm and Naive Bayes Classifier were applied to this obtained data. Moreover, in this study considering the advantages such as the ease of access to the online tests compared to the paper based tests, the need for a specialist in the implementation and evaluation stages, the reliability of the analyzes and the ability to be updated (I. C. Choi, Kim, \& Boo, 2003; Pomplun, Frey, \& Becker, 2002), it is aimed to develop an application based on this model that can be accessed both online and on mobile devices.

The results obtained in this study from the standard evaluation method of KLSI-III were compared with the results of the models created by machine learning techniques such as C4.5 Decision Tree Algorithm, k-Nearest Algorithm and Naive Bayes Classifier. As a result of the analysis made, the best performance is obtained with C4.5 decision tree algorithm with 0.659 accuracy. The model obtained with the C4.5 Decision Tree Algorithm revealed that the 9th question asked for the best learning path was the most decisive factor (root node) in the decision tree. The performance of C4.5 decision tree model was followed by the k-Nearest Neighbor Algorithm with 0.646 accuracy and Naive Bayes Classifier with 0.622 accuracy. In this study, although the C4.5 Decision Tree Algorithm gives the best accuracy, other class-based performance evaluation measures (sensitivity, specificity, positive / negative predictive values, and F1 score) may vary. To illustrate this difference, sensitivity can be examined in terms of Converging, Diverging, Assimilating, and Accommodating classes. The highest sensitivity value of the Converging and Diverging classes is obtained with the C4.5 Decision Tree Algorithm, of the Assimilating class with the Naive Bayes Classifier, and the Accommodating class with the k-Nearest Neighbor Algorithm. In this respect, the use of C4.5 Decision Tree Algorithm produces the most accurate result while evaluating KLSI-III. In the same way, this coincides with the Petchboonmee et al. (2015) best model result. However, the accuracy value of $86.85 \%$ obtained in the related study was not reached (approximately $66 \%$ ). In addition, in studies based on ILS which are performed by Maaliw \& Ballera (2017) and Liyanage et al. (2016), the best performance obtained by $\mathrm{J} 48$ (C4.5), too. However, determinative characteristic of the data set used in the analysis should not be forgotten in data mining and machine learning studies.

It is recommended that applications can be carried out by increasing the number of samples in the dataset for future studies related to the subject. It is believed that higher performance can be achieved in analysis with more data (Raut, 2017; Brownlee, 2016a). It is important to develop such applications on questionnaires, scales or psychological tests which are important in the field of education by using machine learning techniques in future studies. In addition, by choosing the most significant questions from the measurement tools with feature selection methods, the forms can be shortened, and complicated structures can be simplified. Thus, the problems such as lack of motivation of the students in practice, prejudice, misunderstanding of the questions and leaving the questions blank, as expressed by Botsios et al. (2008), and unanswered that result from the excessive number of items in the assessment will be minimized.

The sample of the study is composed of higher education students. Similar analyses can be performed on different sets of sample groups to compare the obtained results. Even if the prediction of learning styles with machine learning techniques was performed in the study, the learning styles needed for the classification were obtained by calculating the data sets that had to comply with the evaluation criteria of KLSI-III. In the future studies, the data set can be clustered by considering machine learning clustering algorithms (or unsupervised learning algorithms) such as k-means, fuzzy c-means, and the learning styles. After that, the clusters can be associated with the learning styles and forwarded to the prediction process. In this way, unlike classification (or supervised learning algorithms) clustering algorithms can group observations together without information about pre-determined learning styles of students. Thus, there will be no need to calculate students' learning styles based on a standard scale. Furthermore, learning styles classes will be created independently of Kolb's original evaluation. It is also believed that repeating the analyses using different classification algorithms such as artificial neural networks, C5.0, or hybrid algorithms may lead researchers to better results. Because, using more advanced, newer and hybrid algorithms are believed to produce more accurate and stronger predictions for the learning styles of students. 
The model with the highest accuracy in the study was integrated to an application which is available online and on mobile devices. In this way, educators who want to organize their learning environments in accordance with students' learning styles have been provided with easy access to the application environment. Furthermore, by sharing machine learning evaluation of KLSI-III in an online environment, the standardization of the management conditions during the implementation of the test, elimination of possible errors in measurement and evaluation processes of a scale used for determination of student's learning styles are ensured and there is no need for a field expert in this process, and regardless of the number of participants, all individuals were allowed to take part in the process under the same conditions (I. C. Choi et al., 2003; Pomplun et al., 2002). Additionally, it is believed that this application will enable an increase in awareness on the importance of the learning styles and contribute to the creation of personal learning environments by integrating similar applications, especially with LMS. In addition, the learning style prediction application developed in this study can be applied to the students at the beginning of the education period in the classroom education, so that the learning styles of the students can be determined. Thus, the trainer can regulate or enrich the curriculum throughout this period. As a natural result of this, the academic success of the students and their motivation towards the lessons are expected to increase (Ming, 2004; Bilgin \& Durmuş, 2003; Kılıç, 2002). As a result; because the application developed within the scope of this study can be easily integrated into e-learning systems by only using its URL; it is thought that it is important for the teachers to facilitate the process of determining the learning styles of the students and accordingly to enable the student-centered design of the training activities and the scientific studies reaching more students. For future studies, it is also aimed to perform machine learning analysis with log data of an LMS course just like the other studies in the literature (Maaliw \& Ballera, 2017; Liyanage et al., 2016; Rajper et al., 2016). Accordingly, authors believe that this will carry KLSI-III based predictions of this study to more student behavior-centered predictions.

\section{Acknowledgement}

This study was carried out by İstanbul University-Cerrahpaşa Hasan Ali Yücel Faculty of Education (HAYEF) Learning Center R\&D Unit. http://ogrenmemerkezi.istanbulc.edu.tr

\section{References}

Abdullah, M., Daffa, W. H., Bashmail, R. M., Alzahrani, M., \& Sadik, M. (2015). The Impact of Learning Styles on Learner's Performance in E-Learning Environment. International Journal of Advanced Computer Science and Applications, 6(9), 24-31. https:// doi.org/10.14569/IJACSA.2015.060903

Acuna, E., \& The CASTLE Research Group. (2015). dprep: Data Pre-Processing and Visualization Functions for Classification. Retrieved from https://CRAN.R-project.org/package=dprep

Aşkar, P., \& Akkoyunlu, B. (1993). Kolb öğrenme stili envanteri. Eğitim ve Bilim, 87, 37-47.

Babadoğan, C. (2000). Öğretim stili odaklı ders tasarımı geliştirme. Milli Eğitim Dergisi, 147, 61-63.

Balaban, M. E., \& Kartal, E. (2018). Veri Madenciliği ve Makine Öğrenmesi Temel Algoritmaları ve R Dili ile Uygulamaları (Second Edition). Beyoğlu, İstanbul: Çağlayan Kitabevi.

Bilgin, İ., \& Durmuş, S. (2003). Öğrenme Stilleri ile Öğrenci Başarısı Arasındaki illişki Üzerine Karşılaştırmalı Bir Araştirma. Educational Sciences: Theory \& Practice, 3(2), 383.

Botsios, S., Georgiou, D., \& Safouris, N. (2008). Contributions to adaptive educational hypermedia systems via on-line learning style estimation. Journal of Educational Technology \& Society, 11(2).

Brown, E., Cristea, A., Stewart, C., \& Brailsford, T. (2005). Patterns in Authoring of Adaptive Educational Hypermedia: A Taxonomy of Learning Styles. Educational Technology \& Society, 8(3), 77-90.

Brown, H. D. (2000). Principles of Language Learning and Teaching (4th Edition). New York, USA: Addison Wesley Longman.

Brownlee, J. (2016a). How To Get Better Machine Learning Performance. Retrieved March 11, 2018, from https://machinelearningmastery.com/machine-learning-performance-improvement-cheat-sheet/

Brownlee, J. (2016b). Supervised and Unsupervised Machine Learning Algorithms. Retrieved March 11, 2018, from https://machinelearningmastery.com/supervised-and-unsupervised-machine-learning-algorithms/

Cassidy, S. (2004). An Overview of Theories, Models, and Measures. Educational Psychology, 24(4), 419-444. https://doi. org/10.1080/0144341042000228834

Chang, W. (2016). shinythemes: Themes for Shiny. Retrieved from https://CRAN.R-project.org/package=shinythemes

Chang, W., Cheng, J., Allaire, J. J., Xie, Y., \& McPherson, J. (2017). shiny: Web Application Framework for R. Retrieved from https:// CRAN.R-project.org/package=shiny

Choi, I. C., Kim, K. S., \& Boo, J. (2003). Comparability of A Paper-Based Language Test and A Computer-Based Language Test. Language Testing, 20(3), 295-320.

| Kastamonu Eğitim Dergisi, 27(5), 2019| 
Cran.r-project.org. (2018). The Comprehensive R Archive Network. Retrieved March 20, 2018, from https://cran.r-project.org/

Douglas, P. K., Harris, S., Yuille, A., \& Cohen, M. S. (2011). Performance Comparison of Machine Learning Algorithms and Number of Independent Components Used in fMRI Decoding of Belief vs. Disbelief. Neurolmage, 56(2), 544-553. https://doi. org/10.1016/j.neuroimage.2010.11.002

Duff, A., \& Duffy, T. (2002). Psychometric Properties of Honey \& Mumford's Learning Styles Questionnaire (LSQ). Personality and Individual Differences, 33(1), 147-163. https://doi.org/10.1016/S0191-8869(01)00141-6

Dunn, R., Beaudry, J. S., \& Klavas, A. (1989). Survey of Research on Learning Styles. Educational Leadership, 46(6), 50-58.

Dunn, R., Honigsfeld, A., Doolan, L. S., Bostrom, L., Russo, K., Schiering, M. S., ... Tenedero, H. (2009). Impact of Learning-Style Instructional Strategies on Students' Achievement and Attitudes: Perceptions of Educators in Diverse Institutions. The Clearing House: A Journal of Educational Strategies, Issues and Ideas, 82(3), 135-140. https://doi.org/10.3200/TCHS.82.3.135-140

Dunn, R. S., \& Dunn, K. J. (1993). Teaching Secondary Students Through Their Individual Learning Styles: Practical Approaches for Grades 7-12. Boston, MA, USA: Pearson Education.

Dunn, R. S., Dunn, K. J., \& Price, G. E. (1989). Learning Style Inventory. Lawrence, KS, USA: Price Systems.

Ekici, G. (2003). Öğrenme Stiline Dayalı Öğretim ve Biyoloji Dersi Öğretimine Yönelik Ders Planı Örnekleri. Ankara: Gazi Kitabevi.

Emre, i. E. (2017). Veri Madenciliği ile Çocukluk Çağındaki Akut Romatizmal Ateşin Kalp Hastalığına Etkilerinin Analizi (Yüksek Lisans Tezi). İstanbul Üniversitesi Fen Bilimleri Enstitüsü, İstanbul.

Evin Gencel, ì. (2006). Öğrenme Stilleri, Deneyimsel Öğrenme Kuramına Dayalı Eğitim, Tutum ve Sosyal Bilgiler Program Hedeflerine Erişi Düzeyi (Doktora Tezi). Dokuz Eylül Üniversitesi, İzmir.

Felder, R. M., Felder, G. N., \& Dietz, E. J. (2002). The Effects of Personality Type on Engineering Student Performance and Attitudes. Journal of Engineering Education, 91(1), 3-17. https://doi.org/10.1002/j.2168-9830.2002.tb00667.x

Felder, R. M., \& Silverman, L. K. (1988). Learning and Teaching Styles in Engineering Education. Engineering Education, 78(7), 674-681.

García, P., Amandi, A., Schiaffino, S., \& Campo, M. (2007). Evaluating Bayesian Networks' Precision for Detecting Students' Learning Styles. Computers \& Education, 49(3), 794-808. https://doi.org/10.1016/j.compedu.2005.11.017

Garg, B. (2013). Design and Development of Naive Bayes Classifier (Master of Science Thesis). North Dakota State University, North Dakota.

Ghazivakili, Z., Nia, R. N., Panahi, F., Karimi, M., Gholsorkhi, H., \& Ahmadi, Z. (2014). The Role of Critical Thinking Skills and Learning Styles of University Students in Their Academic Performance. Journal of Advances in Medical Education \& Professionalism, 2(3), 95-102.

Gilakjani, A. P. (2012). Visual, Auditory, Kinaesthetic Learning Styles and Their Impacts on English Language Teaching. Journal of Studies in Education, 2(1), 104. https://doi.org/10.5296/jse.v2i1.1007

Gooden, D. J., Preziosi, R. C., \& Barnes, F. B. (2009). An Examination of Kolb's Learning Style Inventory. American Journal of Business Edution, 2(3), 57-62. https://doi.org/10.19030/ajbe.v2i3.4049

Gregorc, A. (1982). Gregorc Style Delineator: Development, Technical, And Administration Manual. Gabriel Systems, Inc.: Maynard, MA, USA.

Griggs, S., \& Dunn, R. (1996). Hispanic-American Students and Learning Styles. East Lansing, MI: National Center for Research on Teacher Learning. ERIC, Document Reproduction Service no. ED 393607.

Grigorenko, E. L., \& Sternberg, R. J. (1995). Thinking Styles. In D. H. Saklofske \& M. Zeidner (Eds.), International Handbook of Personality and Intelligence (pp. 205-229). New York, USA: Plenum Press.Gülbahar, Y. (2005). Öğrenme Stilleri ve Teknoloji. Eğitim ve Bilim, 30(138), 10-17.

Han, J., \& Kamber, M. (2006). Data Mining: Concepts and Techniques (2nd ed.). San Francisco, CA, USA: Morgan Kaufmann Publishers.

Hein, T. L., \& Budny, D. D. (1999). Teaching to Students' Learning Styles: Approaches That Work (Vol. 2, pp. 12C1/7-12C114). Presented at the Frontiers in Education Conference, Stripes Publishing L.L.C. https://doi.org/10.1109/FIE.1999.841622

Helmy, Y., Abdo, A., \& Abdallah, R. (2016). A Proposed Framework for Learning Style Prediction in Higher Education Environments. International Journal of Advanced Research in Computer Science and Software Engineering, 6(3), $140-143$.

Hmedna, B., El Mezouary, A., Baz, O., \& Mammass, D. (2017). Identifying And Tracking Learning Styles in MooCs: A Neural Networks Approach. International Journal of Innovation and Applied Studies, 19(2), 267.

Hornik, K., Buchta, C., \& Zeileis, A. (2009). Open-Source Machine Learning: R Meets Weka. Computational Statistics, 24(2), 225232. https://doi.org/10.1007/s00180-008-0119-7

Kagan, J., Rosman, B. L., Day, D., Albert, J., \& Phillips, W. (1964). Information Processing in The Child: Significance of Analytic and Reflective Attitudes. Psychological Monographs: General and Applied, 78(1), 1-37. https://doi.org/10.1037/h0093830 
Kahtz, A. W., \& Kling, G. J. (1999). Field-dependent and Field-independent Conceptualisations of Various Instructional Methods with an Emphasis on CAl: a qualitative analysis. Educational Psychology, 19(4), 413-428. https://doi. org/10.1080/0144341990190403

Karasar, N. (2003). Bilimsel Araştırma Yöntemi: Kavramlar-ilkeler-Teknikler. Ankara: Nobel Yayın Dağıtım.

Kartal, E., \& Özen, Z. (2017). Dengesiz Veri Setlerinde Sınıflandırma. In O. Torkul, S. Gülseçen, Y. Uyaroğlu, G. Çağıl, \& M. K. Uçar (Eds.), Mühendislikte Yapay Zeka ve Uygulamaları (Birinci, pp. 109-131). Sakarya: Sakarya Üniversitesi Kütüphanesi Yayınevi.

Kaufmann, G. (1989). The Assimilator-Explorer Inventory. Bergen, Norway: University of Bergen, Department of General Psychology, Cognitive Unit.

Kharb, P., Samanta, P. P., Jindal, M., \& Singh, V. (2013). The Learning Styles and The Preferred Teaching-Learning Strategies of First Year Medical Students. Journal of Clinical and Diagnostic Research: JCDR, 7(6), 1089.

Kinshuk, Liu, T. C., \& Graf, S. (2009). Coping with Mismatched Courses: Students' Behaviour and Performance in Courses Mismatched to Their Learning Styles. Educational Technology Research and Development, 57(6), 739-752. https://doi.org/10.1007/ s11423-009-9116-y

Kılıç, E. (2002). Baskın Öğrenme Stilinin Öğrenme Etkileri Tercihi ve Akademik Başarıya Etkisi. Eğitim Bilimleri ve Uygulama, 1(1), 1-15.

Kolb, D. A. (1984). Experiential Learning. NJ, USA: Prentice-hall Englewood Cliffs.

Kolb, D. A. (1985). Learning-Style Inventory: Self-Scoring Inventory and Interpretation Booklet: Revised Scoring. Boston: Mc Beer and Company.

Kolb, D. A. (1999). The Kolb Learning Style Inventory, Version 3. Boston, MA, USA: Hay Resources Direct.

Kotsiantis, S. B. (2007). Supervised Machine Learning: A Review of Classification Techniques. Informatica 31, $249-268$.

Kuhn, M. (2017). caret: Classification and Regression Training. Retrieved from https://CRAN.R-project.org/package=caret

Larrañaga, P. (2006). K-Nearest Neighbor. Retrieved from http://biocomp.cnb.csic.es/ coss/Docencia/ADAM/Sample/Sample_ Classification.pdf

Li, Y. S., Yu, W. P., Liu, C. F., Shieh, S. H., \& Yang, B. H. (2014). An Exploratory Study of The Relationship Between Learning Styles and Academic Performance Among Students in Different Nursing Programs. Contemporary Nurse, 48(2), $229-239$.

Liyanage, M. P. P., Gunawardena, K. L., \& Hirakawa, M. (2016). Detecting Learning Styles in Learning Management Systems Using Data Mining. Journal of Information Processing, 24(4), 740-749. https://doi.org/10.2197/ipsjjip.24.740

Logan, K., \& Thomas, P. (2002). Learning Styles in Distance Education Students Learning to Program (pp. 29-44). Presented at the 14th Workshop of the Psychology of Programming Interest Group, Brunel University, London, UK. Retrieved from http://www. ppig.org/papers/14th-logan.pdf

Lovelace, M. K. (2005). Meta-Analysis of Experimental Research Based on The Dunn and Dunn Model. The Journal of Educational Research, 98(3), 176-183.

Lowy, A., \& Hood, P. (2004). The Power of the 2 × 2 Matrix: Using $2 \times 2$ Thinking to Solve Business Problems and Make Better Decisions. San Francisco, CA, USA: John Wiley \& Sons.

Maaliw, R. R. I., \& Ballera, M. A. (2017). Classification of Learning Styles in Virtual Learning Environment Using J48 Decision Tree. Presented at the 14th International Conference on Cognition and Exploratory Learning in Digital Age (CELDA 2017).

McKenna, L., Copnell, B., Butler, A. E., \& Lau, R. (2018). Learning Style Preferences of Australian Accelerated Postgraduate Pre-Registration Nursing Students: A Cross-Sectional Survey. Nurse Education in Practice, 28, 280-284. https://doi.org/10.1016/j. nepr.2017.10.011

Metallidou, P., \& Platsidou, M. (2008). Kolb's Learning Style Inventory-1985: Validity Issues And Relations with Metacognitive Knowledge About Problem-Solving Strategies. Learning and Individual Differences, 18(1), 114-119. https://doi.org/10.1016/j. lindif.2007.11.001

Meyer, D., Dimitriadou, E., Hornik, K., Weingessel, A., \& Leisch, F. (2017). e1071: Misc Functions of the Department of Statistics, Probability Theory Group (Formerly: E1071), TU Wien. Retrieved from https://CRAN.R-project.org/package=e1071

Ming, C. S. (2004). Effects of Programmed Learning Sequences Versus Traditional Instruction on The Achievement And Attitudes of Bermudian Seventh Graders in Social Studies And The Comparison of Two Learning-Style Identification Instruments' Interpretations (Doctoral Thesis). St. John's University.

Mitchell, T. M. (1997). Machine Learning (1st ed.). USA: The McGraw-Hill Companies, Inc.

Moussa, N. (2014). The Importance of Learning Styles in Education. Institute for Learning Styles Journal, 1, $19-27$.

Mumford, A., \& Honey, P. (1992). Questions and Answers on Learning Styles Questionnaire. Industrial and Commercial Training, 24(7). https://doi.org/10.1108/00197859210015426

Narlı, S., Aksoy, E., \& Ercire, Y. E. (2014). Investigation of Prospective Elementary Mathematics Teachers' Learning Styles and Relationships Between Them Using Data Mining. International Journal of Educational Studies in Mathematics, 1(1), $37-57$.

| Kastamonu Eğitim Dergisi, 27(5), 2019| 
Okur, M., \& Bahar, H. H. (2010). Learning Styles of Primary Education Prospective Mathematics Teachers; States of Trait-Anxiety and Academic Success. Procedia-Social and Behavioral Sciences, 2(2), 3632-3637. https://doi.org/10.1016/j.sbspro.2010.03.565

Özen, Z. (2016). Kimlik Doğrulaması için Tuş Vuruş Dinamiklerine Dayalı Bir Güvenlik Sisteminin Yapay Sinir Ağları ile Geliştirilmesi (Doktora Tezi). İstanbul Üniversitesi Fen Bilimleri Enstitüsü, İstanbul.

Pantho, O., \& Tiantong, M. (2016). Using Decision Tree C4. 5 Algorithm to Predict VARK Learning Styles. International Journal of the Computer, the Internet and Management, 24(2), 58-63.

Pashler, H., McDaniel, M., Rohrer, D., \& Bjork, R. (2009). Learning Styles Concepts and Evidence. Psychological Science in The Public Interest, 9(3), 105-119. https://doi.org/10.1111/j.1539-6053.2009.01038.x

Peker, M. (2003). Kolb Öğrenme Stili Modeli. Milli Eğitim Dergisi, 157, 185-192.

Petchboonmee, P., Phonak, D., \& Tiantong, M. (2015). A Comparative Data Mining Technique for David Kolb's Experiential Learning Style Classification. International Journal of Information and Education Technology, 5(9), 672-675. https://doi.org/10.7763/ IJIET.2015.V5.590

Peterson, E. R., Deary, I. J., \& Austin, E. J. (2003). The Reliability of Riding's Cognitive Style Analysis Test. Personality and Individual Differences, 34(5), 881-891. https://doi.org/10.1016/S0191-8869(02)00116-2

Pomplun, M., Frey, S., \& Becker, D. F. (2002). The Score Equivalence of Paper-and-Pencil and Computerized Versions of A Speeded Test of Reading Comprehension. Educational and Psychological Measurement, 62(2), 337-354.

Poon Teng Fatt, J. (2000). Understanding The Learning Styles of Students: Implications for Educators. International Journal of Sociology and Social Policy, 20(11/12), 31-45.

Rajper, S., Shaikh, N. A., Shaikh, Z. A., \& Ali Mallah, G. (2016). Automatic Detection of Learning Styles on Learning Management Systems using Data Mining Technique. Indian Journal of Science and Technology, 9(15), 1-5. https://doi.org/10.17485/ ijst/2016/v9i15/85959

Raut, S. (2017). 5 Ways to Improve The Model Accuracy of Machine Learning. Retrieved March 11, 2018, from https://www.datasciencecentral.com/profiles/blogs/5-ways-to-improve-the-model-accuracy-of-machine-learning

Riding, R. (2002). The Nature and Effects of Cognitive Style. In R. J. Sternberg \& L. F. Zhang (Eds.), Perspectives on thinking, learning, and cognitive styles (pp. 47-72). NJ, USA: Lawrence Erlbaum Associates.

Riding, R. J. (1991). Cognitive Styles Analysis - CSA Administration. Birmingham: Learning and Training Technology.

Riding, R., \& Rayner, S. (2013). Cognitive Styles and Learning Strategies: Understanding Style Differences in Learning and Behavior. New York, NY, USA: Routledge.

RStudio. (2017a). Shiny. Retrieved March 20, 2018, from https://shiny.rstudio.com/

RStudio. (2017b). shinyapps.io. Retrieved March 20, 2018, from https://www.shinyapps.io/

RStudio. (2018). RStudio - Open Source and Enterprise-Ready Professional Software for R. Retrieved March 20, 2018, from https://www.rstudio.com/

Samancı, N. K., \& Keskin, M. Ö. (2007). Felder ve Soloman Öğrenme Stili İndeksi: Türkçeye Uyarlanması ve Geçerlik-Güvenirlik Çalışması. Ahi Evran Üniversitesi Kırşehir Eğitim Fakültesi Dergisi, 8(2).

Sayad, S. (2017). Naive Bayesian. Retrieved May 27, 2017, from http://www.saedsayad.com/naive_bayesian.htm

Shearer, C. (2000). The CRISP-DM Model: The New Blueprint for Data Mining. Journal of Data Warehousing, 5(4), $13-22$.

Simpson, C., \& Du, Y. (2004). Effects of Learning Styles and Class Participation on Students' Enjoyment Level in Distributed Learning Environments. Journal of Education for Library and Information Science, 45(2), 123-136. https://doi.org/10.2307/40323899

Şimşek, Ö. (2007). Marmara Öğrenme Stilleri Ölçeği'nin Geliştirilmesi ve 9-11 Yaş Çocuklarının Öğrenme Stillerinin İncelenmesi (Doktora Tezi). Marmara Üniversitesi. Eğitim Bilimleri Enstitüsü, İstanbul.

Tanabe, H. (2006). Effects of Teaching Styles on Motivation for Self-Training by Students in Teaching of Presentation in L2. Academic Reports, Tokyo Polytechnic University, 28(2), 1-7.

Truong, H. M. (2015). Integrating Learning Styles into Adaptive E-Learning System. In O. C. Santos, J. G. Boticario, C. Romero, M. Pechenizkiy, A. Merceron, P. Mitros, ... M. Desmarais (Eds.) (pp. 645-647). Presented at the 8th International Conference on Educational Data Mining, Madrid, Spain. Retrieved from http://www.educationaldatamining.org/EDM2015/proceedings/ edm2015_proceedings.pdf

Uysal, M., Balbal, K. F., Mülayim, N., Özdemir, A., \& Albeyoğlu, A. (2016). A Learning Style Inference System Based on Fuzzy Logic Technique. In The Eurasia Proceedings of Educational \& Social Sciences (Vol. 4, pp. 590-597).

Uysal, M. P. (2010). Öğrenme Stillerinin Bulanık Mantıkla Modellenmesi. In 4th International Computer \& Instructional Technologies Symposium (pp. 1040-1045). Selçuk University Konya, Turkey.

Vermunt, J. D., \& Vermetten, Y. J. (2004). Patterns in Student Learning: Relationships Between Learning Strategies, Conceptions of Learning, and Learning Orientations. Educational Psychology Review, 16(4), 359-384.

Veznedaroğlu, R. L., \& Özgür, A. O. (2005). Öğrenme Stilleri: Tanımlamalar, Modeller ve İşlevleri. İlköğretim Online, 4(2). 
Visser, S., McChlery, S., \& Vreken, N. (2006). Teaching Styles Versus Learning Styles in The Accounting Sciences in The United Kingdom and South Africa: A Comparative Analysis. Meditari Accountancy Research, 14(2), 97-112. https://doi. org/10.1108/10222529200600015

Wickham, H. (2011). The Split-Apply-Combine Strategy for Data Analysis. Journal of Statistical Software, 40(1), 1-29.

Williams, N., Zander, S., \& Armitage, G. (2006). A Preliminary Performance Comparison of Five Machine Learning Algorithms for Practical IP Traffic Flow Classification. ACM SIGCOMM Computer Communication Review, 36(5), 5-16.

Witkin, H. A., Oltman, P. F., Raskin, E., \& Karp, S. A. (1971). Children's Embedded Figures Test. Palo Alto, CA: Consulting Psychologist Press, Inc.

Witten, I. H., \& Frank, E. (2005). Data Mining: Practical Machine Learning Tools and Techniques (2nd ed.). Cambridge, MA, USA: Morgan Kaufmann.

Xu, Z., \& Shi, Y. (2018). Application of Constructivist Theory in Flipped Classroom-Take College English Teaching as A Case Study. Theory and Practice in Language Studies, 8(7), 880-887.

Yang, J., Huang, Z. X., Gao, Y. X., \& Liu, H. T. (2014). Dynamic Learning Style Prediction Method Based on a Pattern Recognition Technique. IEEE Transactions on Learning Technologies, 7(2), 165-177. https://doi.org/10.1109/TLT.2014.2307858

Zajacova, B. (2013). Learning Styles: An Overview of Concepts and Research Tools and Introduction of Our Research Design in Physics Education Field. In WDS'13 Proceedings of Contributed Papers (Vol. Part III, pp. 91-96).

Zhang, L.F., Sternberg, R. J., \& Rayner, S. (Eds.). (2011). Handbook of Intellectual Styles: Preferences in Cognition, Learning, and Thinking. New York, NY, USA: Springer Publishing Company. 